\title{
The nasal cycle: a comprehensive review*
}

\section{Alfonso Luca Pendolino', Valerie J. Lund², Ennio Nardello', Giancarlo Ottaviano'}

' Department of Neurosciences, Otolaryngology Section, University of Padova, Padova, Italy

2 Ear Institute, University College London, London, United Kingdom
Rhinology Online, Vol 1: 67-76, 2018

http://doi.org/10.4193/RHINOL/18.021

*Received for publication:

May 7, 2018

Accepted: June 5, 2018

Published: June 17, 2018

\begin{abstract}
Background: The nasal cycle is the spontaneous, reciprocal congestion and decongestion of the nasal mucosa during the day and it is present in almost $70-80 \%$ of healthy adults. The German physician Richard Kayser first described it in 1895 . Since then, the number of papers focused on this fascinating issue has continued to flourish.

Main body: Even though there are a high number of publications on this topic, the understanding of nasal cycle is still very poor. The present review tries to offer a comprehensive analysis of this issue investigating all the physiologic and pathologic conditions able to modify the nasal cycle. A section of methods used for its evaluation has been also included in this review.

Conclusion: The influence of the nasal cycle on nasal airflow must be considered during any rhinologic evaluation, especially if investigating the need for septal/turbinates surgery, rather than nasal medical therapy alone. The nasal cycle is a normal phenomenon and must be recognized in order to differentiate it from the pathologic causes of nasal obstruction.
\end{abstract}

Key words: nasal cycle, nasal patency, nasal airflow, nasal mucosa, pattern, congestion, decongestion

\section{Introduction}

The nasal cycle (NC) is the spontaneous congestion and decongestion of the nasal mucosa during the day, where congestion of one side is accompanied by reciprocal decongestion of the contralateral side (Figure1). It is based on the dilation/constriction of the venous cavernous tissue in the submucosa of the turbinates and septum ${ }^{(1)}$, but also of the ethmoid sinuses ${ }^{(2)}$. It is accepted that almost $70-80 \%$ of adults experience a regular NC, but a true periodicity/reciprocity exists only in $21-39 \%$ of the population ${ }^{(3,4)}$. NC is considered an ultradian rhythm of side-toside nasal mucosal engorgement with a phase length ranging from $30 \mathrm{~min}$ to $6 \mathrm{~h}^{(5)}$. As first described, in an ideal cycle, the two air passages should show reciprocal changes of equal amplitude, $180^{\circ}$ out of phase, with an identical period and similar mean airflow, with total nasal flow remaining constant ${ }^{(6)}$. Anyway, a NC so described is barely found, because at least one of these three characteristics is not fulfilled $^{(7)}$. This paper presents a review of the literature with the aim to offer an organized presentation issue.

\section{Literature search and selection}

A PubMed database search was conducted until March 2018. The initial search yielded a total of 199 publications, published from January 1953 to March 2018. The term "nasal cycle" was used as key word in the title or in the abstract using PubMed advanced search. References were screened for further relevant articles. We excluded papers not written in English, German, French, Spanish or Italian $(n=15)$ and letters to the editor $(n=3)$. After an initial reading of the abstract, articles considered not relevant to the topic were excluded $(n=60)$. A further 11 papers were added after a manual search, while 9 papers were excluded after a full text revision. Finally, 123 papers were considered for 


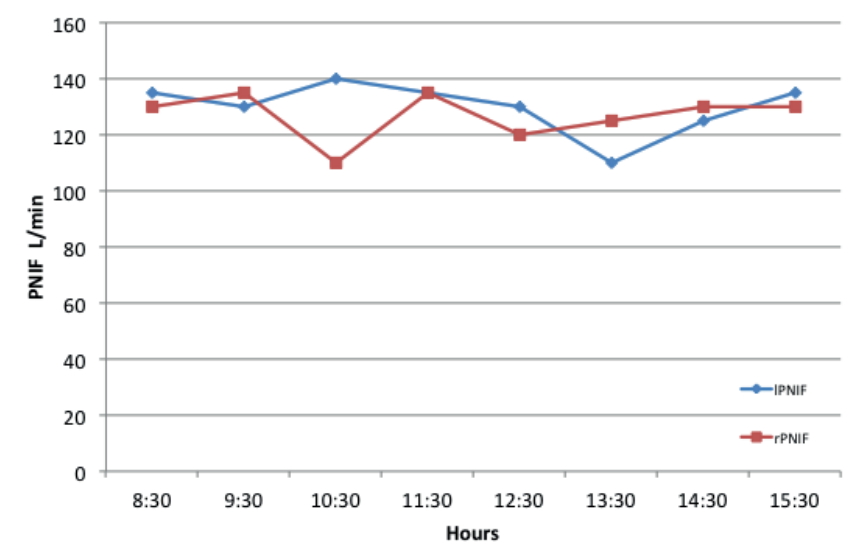

Figure 1. Example of nasal cycle measured by means of Peak Nasal Inspiratory Flow measurements over a period of 7 hours [in red the right nostril (rPNIF), in blue the left nostril (IPNIF)].

the review. ALP and EN performed the PubMed research and the revision of the papers.

\section{Hypothesis on NC role}

First Wright ${ }^{(8)}$ and subsequently other authors ${ }^{(4,9-10)}$ thought NC was involved in the production of nasal secretions. Periodic congestion and decongestion of the nasal venous sinusoids in the context of a NC, in fact, acts as an active pumping mechanism to form a plasma exudate ${ }^{(11-12)}$. NC probably exists because of the need to top up the water percentage of the nasal mucus, maintaining humidification of inspired air ${ }^{(13)}$. Eccles was the first to link the NC with a role in respiratory defence ${ }^{(14)}$. Plasma is rich in immunoglobulins and proteins involved in the generation of inflammatory mediators, components important in the defence against infection. During nasal infection, the NC increases its amplitude and frequency, and this may enhance the generation of plasma exudate ${ }^{(15-16)}$. White suggested that the NC enables the upper airway to accommodate the contrasting roles of air conditioning (heating and humidifying of the inhaled air) and removal of entrapped contaminants, through fluctuation in airflow. An efficient transport of entrapped inhaled pathogens and pollutants requires low air velocities and sustained airway surface liquid hydration to be carried out by the congested side of the nose. Conversely, the patent side experiences high air velocities causing recurring severe airway surface liquid dehydration that leads to humidification and temperature regulation of the inhaled air ${ }^{(17)}$.

It has also been hypothesised that the NC allows local accumulation of nitric oxide (NO), which has an important role in modulating epithelial function and antimicrobial features ${ }^{(18)}$.

According to another hypothesis, the NC reflects the dynamic lateralisation of the autonomic nervous system (ANS), with sympathetic activity induced by left brain hemisphere stimulation and parasympathetic activity induced by right hemisphere sti- mulation $^{(19-20)}$. In fact, forced unilateral nostril breathing induces selective contralateral hemispheric stimulation ${ }^{(21)}$ as well as alternating lateralisation of plasma catecholamines production ${ }^{(22)}$. The NC, as an example of lateralised autonomic function, and as part of lateralised neural rhythms, can be considered an integral part of the hypothesis of the basic rest-activity cycle which reflects the needs of any organism to rest and save energy ${ }^{(23-25)}$.

\section{Patterns}

Classically, four types of NC have been described with frequencies reported for each pattern often discordant. The "non-cycle nose" was first described in 1981 meaning a nose which does not exhibit cyclic nasal airflow changes ${ }^{(26)}$. More recently, using acoustic rhinometry (AR), Alnselmo-Lima and Lund tried to define more precisely four types of $\mathrm{NCs}^{(27)}$ :

- Classic (reciprocal congestion/decongestion alterations and a constant total volume);

- Parallel (congestion or decongestion appearing in both nasal cavities at the same time);

- Irregular (mutual alteration in nasal volume without a defined pattern and a constant total nasal volume);

- No pattern (total nasal volume and nasal volume in each nostril do not differ).

NC patterns may transform from one to another in the same subject $^{(27)}$, with patterns' shifts that could be influenced by environmental or physical factors ${ }^{(28)}$. Although it was reported that the reciprocal changes in unilateral airflow are present in the majority of subjects ${ }^{(29)}$, in a recent work a parallel pattern was observed in half of the subjects, while the other half showed a reciprocal pattern ${ }^{(30)}$.

Independently of the type of pattern, individuals usually are not aware of their NC.

\section{NC control}

Congestion and decongestion of the nasal venous cavernous tissue is under the control of the $\mathrm{ANS}^{(31-33)}$. Nasal venous sinusoids have a dense adrenergic innervation ${ }^{(34)}$, and stimulation of these fibres causes the release of noradrenaline, which results in vasoconstriction and in a reduction of nasal airway resistances (NAR) (35). Physiologically, there is a sympathetic tone at the level of the nasal venous sinusoids and the transection or a local anaesthesia of the cervical sympathetic nerves evokes ipsilateral nasal congestion ${ }^{(36)}$. High spinal cord injury (>T1) is associated with immediate loss of the NC, which appears to slowly recover with time ${ }^{(37)}$. Selective block of the stellate ganglion is able to alter the $\mathrm{NC}$ of the homolateral side, leading to a swelling of the inferior concha accompanied by a pronounced increase of NAR, with a moderate rise of NAR in the contralateral side ${ }^{(38)}$.

The central regulation of the sympathetic activity at the level of the nose is not completely understood. Hypothalamus has been suggested to be the central controller ${ }^{(39,40)}$. In 1983, Eccles 
Table 1. Main physiologic conditions influencing nasal cycle.

\begin{tabular}{|c|c|c|}
\hline Condition & Effect & Note \\
\hline Age & $\begin{array}{l}\text { Nasal cycle changes with age probably due } \\
\text { to the maturation of the autonomic nervous } \\
\text { system }{ }^{(36,53)} \text {. }\end{array}$ & $\begin{array}{l}\text { Neonates: most of the neonates shows no significant fluctuations in } \\
\text { nasal patency }{ }^{(51)} \text {. } \\
\text { Children: shorter cycles than adults with regular pattern of fluctuati- } \\
\text { ons of the nasal resistance }{ }^{(55)} \text {. } \\
\text { Adults: classic pattern, with reciprocal congestion/decongestion alte- } \\
\text { rations is the most frequent type reported in literature }{ }^{(53)} \text {. } \\
\text { Elderly: alternating rhythmicity associated with the nasal cycle decrea- } \\
\text { ses with age }{ }^{(59,61)} \text {. }\end{array}$ \\
\hline Sleep & Nasal cycle and sleep stage are correlated ${ }^{(62)}$. & $\begin{array}{l}\text { Increase in cycle duration with a significant decrease in the rate of the } \\
\text { reversal of nasal cycle. Most of the spontaneous changes occur during } \\
\text { REM sleep }{ }^{(63,64)} \text {. } \\
\text { Synchronization of nasal and sleep cycles }{ }^{(65)} \text {. }\end{array}$ \\
\hline Posture & $\begin{array}{l}\text { Lateral recumbency produces nasal cycle chan- } \\
\text { ges }^{(69,72)} \text {. }\end{array}$ & $\begin{array}{l}\text { Changes of the nasal cycle may coincide with switches in posture } \\
\text { from supine to lateral decubitus in some } \text { cases }^{(66)} \text {. }\end{array}$ \\
\hline Mucociliary clearance & $\begin{array}{l}\text { Nasal cycle has a marked effect on the mucocili- } \\
\text { ary clearance of the nose }{ }^{(80)} \text {. }\end{array}$ & $\begin{array}{l}\text { Literature data are controversial on which side the mucociliary clea- } \\
\text { rance is enhanced }{ }^{(80-83)} \text {. }\end{array}$ \\
\hline Exercise & Exercise influences nasal cycle ${ }^{(84)}$. & $\begin{array}{l}\text { In the post-exercise period, spontaneous variations of the nasal cycle } \\
\text { increase in amplitude }{ }^{(87)} \text {. }\end{array}$ \\
\hline Olfactory perception & $\begin{array}{l}\text { Difference in nasal airflow results in a disparity of } \\
\text { olfactory perception }{ }^{(90)} \text {. }\end{array}$ & \\
\hline Humidity & $\begin{array}{l}\text { May affect nasal cycle frequency and ampli- } \\
\text { tude }{ }^{(4)} \text {. }\end{array}$ & \\
\hline Oestrogen & $\begin{array}{l}\text { Oestrogen peak during ovulation is often accom- } \\
\text { panied by nasal congestion, which alters normal } \\
\text { nasal cycle }{ }^{(93,98)} \text {. }\end{array}$ & \\
\hline
\end{tabular}

hypothesised that reciprocal changes in sympathetic tone may be regulated by a "central rhythm" of nervous activity and by sensory input of the nasal mucosa, while in phase changes may be caused by a loose coupling between groups of nasal vasomotor neurons and respiratory neurons ${ }^{(32)}$. Recently, the same group proposed a control model involving a hypothalamic centre and two brainstem half centres ${ }^{(29)}$. Bremner showed that variations in sympathetic "tone" at the level of the nasal vessel are perfectly synchronized with variations at the level of the iris muscles, implying that both are under the control of the same central oscillator ${ }^{(41)}$.

However, it must be considered that a variety of external stimuli, such as exercise ${ }^{(42)}$, arterial $\mathrm{pCO}_{2}{ }^{(43)}$, emotion ${ }^{(44)}$ and skin temperature changes ${ }^{(45-46)}$, are able to influence the activity of the nasal centres ${ }^{(29)}$. Airflow through the nose has been supposed to be important in the control of the nasal vasomotor activity ${ }^{(47)}$. Nevertheless, studies have shown the presence of the NC even in laryngectomized patients, albeit of lower amplitude, in the absence of nasal airflow ${ }^{(48-49)}$. Hildebrandt suggested the presence of a trigger mechanism of the NC linked to the epithelial lining fluid. A flip-flop circuit could be triggered through a binary signal that can release a set or reset impulse when a certain discrepancy between the nasal cavities is constituted in regard to the occurrence of wall shear stress and the size of the transepithelial potential(50).

\section{Physiology of NC (Table1)}

\section{Age}

Usually NC is not present at birth or it is quite rare $\mathrm{e}^{(51,52)}$. The exact period when NC appears is not known, but it could occur with the change from obligate to facultative nasal breathing. Once appeared, NC changes with age. Children show shorter cycles than in adults, with smaller amplitude of fluctuation in the latter. The mechanism for the age-related change of the NC is not clear, but it seems that the maturation of the ANS during the years may explain it ${ }^{(36,53)}$. Mayer found a NC in $79 \%$ of children aged 7-10 years and in 50\% of children aged 3-6 years ${ }^{(54)}$. Children showed to have a regular pattern of fluctuations of the NAR, with fluctuations happening in phase ${ }^{(55)}$. Fisher evaluating NC in children found classic pattern to be the predominant one ${ }^{(56)}$. In contrast Gallego found that the irregular pattern was the most frequent pattern in children, hypothesising that the immature central control of the NC may explain the passage from an irregular pattern to a classical one with time ${ }^{(57)}$. With aging, peripheral factors [i.e.changes in the vascular elasticity of the nasal epithelium) $\left.{ }^{(58)}\right]$ and central factors (alterations in central brain mechanisms) may induce changes in $\mathrm{NC}(59,60)$. Therefore, the alternating rhythmicity associated with the NC decreases with age ${ }^{(59,61)}$.

\section{Sleep}

It seems that there is a correlation between sleep stages and 
changes in NAR. Kimura observed an increase in NC duration during sleep and a decrease in the reversal rate of the NC. In $84.6 \%$ of cases, spontaneous changes of the NC occurred during the rapid eye movement (REM) sleep ${ }^{(62)}$. This may be related to a strong sympathetic activation during REM phase that shifts to a parasympathetic dominance in slow wave sleep ${ }^{(63,64)}$. During the night sleep, nasal and sleep cycles may become synchronized, so that NC duration is one or more times the duration of the sleep cycle ${ }^{(65)}$. Rohrmeier found that in normal conditions, NC period, amplitude and duration are significantly greater during sleep than during wakefulness ${ }^{(66)}$. A relationship between the rhythms of the NC and sleep stage has been confirmed by Frye ${ }^{(67)}$. Recently, Ozturk observed that sleep efficiency, NREM stage III, and total sleep duration were greater during left nasal obstruction (right nostril dominant respiration), while apneahypopnea-index, frequency of periodic limb movements, and oxygen desaturation were higher during right nasal obstruction (left nostril dominant respiration) ${ }^{(68)}$. However, NC changes are also strictly linked to the posture adopted.

\section{Posture}

Posture changes can influence nasal airflow ${ }^{(69-72)}$. The transition from sitting to supine causes an increase in central venous pressure of up to $8 \mathrm{mmHg}$ due to an increase in hydrostatic pressure ${ }^{(73)}$. This leads to an increase in congestion of the nasal mucosa and higher NAR independently from the sympathetic control due to the $\mathrm{NC}^{(74,75)}$. Increased NAR are observed in lateral recumbency where the inferior nostril becomes the congested side. During sleep, changes in NC may coincide with switches in posture from supine to lateral decubitus ${ }^{(62,76)}$. Rohrmeier found a phase reversal in the NC after positional shifts in $22 \%$ of the subjects $^{(66)}$. Positional shifts result in early adjustment of the $\mathrm{NC}$, but it soon reverts to its spontaneous pattern if a constant position is maintained ${ }^{(66,75)}$. In these changes, positional shifts of the entire body, and not only of the head, appear to be the most important factor. A corporo-nasal reflex, well known by yogis who use it to influence mind-body states, seems to underlie this phenomenon ${ }^{(75-77)}$. During postural shifts, the reflex overrides the NC inhibiting it temporarily, but when a lateral posture is sustained, $\mathrm{NC}$ begins again with its phase reverted ${ }^{(78)}$. Hence for a subject with a unilateral septal deviation (NSD), the lateral recumbency on the narrowest side will render the superior side more patent, as a consequence of the corporo-nasal reflex, but if this posture is maintained, the recovery of the NC will spontaneously reverse NAR. NC and postural reflexes may also, in part, explain the breathing disorders during sleep in patients with NSD ${ }^{(79)}$.

\section{Role of NC in respiratory defence}

Although it seems that NC may influence mucociliary clearance (MC), data are controversial. A difference of the $\mathrm{MC}$ in the two phases of the NC was observed, with a faster clearance rate when the nasal passage is more patent ${ }^{(80)}$. Conversely, Littlejohn stated that MC is enhanced in the congested phase ${ }^{(81)}$, while Ingels did not find any relation between the ciliary beat frequency and the degree of patency ${ }^{(82)}$. Recently, Soane reported MC to be greater in the patent side than in the obstructed one ${ }^{(83)}$. The variability of the results probably lies in the different methods used or on the criteria used to demonstrate that these differences between nasal passages exist. Sympathetic changes may account for the differences in transport rates, but the reason for a MC difference during the $\mathrm{NC}$ is not yet completely understood.

\section{Exercise}

Exercise strongly influences nasal airflow ${ }^{(84)}$. The main mechanism responsible for the increase in nasal patency during exercise is played by the sympathetic nervous system which causes a mucosa decongestion with an increase in the nasal airway volume ${ }^{(85)}$. The increase in nasal volume is transitory, with a greater decline occurring during the first 10 minutes after the cessation of exercise and with a return to the resting values of nasal volume within 20 minutes after the end of exercise ${ }^{(85-86)}$. Hilberg found that in the post-exercise period spontaneous variations of the NC are increased in amplitude ${ }^{(87)}$.

\section{Other factors}

$\mathrm{NC}$ is coupled to an alternating lateralisation of cerebral hemispheric activity in humans ${ }^{(19)}$. It is possible that the hemisphere contralateral to the dominant nostril (which has the highest sympathetic tone) would have a greater blood flow as a result of the simultaneous parasympathetic activation ${ }^{(23)}$. A significant relationship between the pattern of nasal airflow and spatial vs. verbal performance has also been reported ${ }^{(88-89)}$.

NC was demonstrated to influence olfactory perception: mucosal swelling that cyclically obstructs each nostril causes odorants to be drawn into the nostrils at different rates ${ }^{(90)}$. Olfaction seems not to be influenced by exercise and this can be explained by the fact that the active vasoconstriction of nasal mucosa demonstrated during physical exercise could also be associated with a similar reduction of blood flow to the olfactory cells, thus compensating for the higher flow of odorants reaching the olfactory cleft ${ }^{(42)}$. In one patient with chronic rhinosinusitis, it has been suggested that NC can modify olfactory perception, even when there is no major effect on nasal patency ${ }^{(91)}$.

NC has also been hypothesised to influence eustachian tube function and middle ear pressure. However, Knight reported that nasal mucosal changes occurring during the NC do not affect the eustachian tube function ${ }^{(92)}$.

Also humidity of the inspired air may affect NC frequency and amplitude ${ }^{(4)}$.

No relationship has been found between NAR and skin temperature although both are controlled by the sympathetic vasocon- 
Table 2. Main pathologic conditions influencing nasal cycle.

\begin{tabular}{|c|c|c|}
\hline Condition & Effect & Note \\
\hline $\begin{array}{l}\text { Acute upper respira- } \\
\text { tory tract infection }\end{array}$ & $\begin{array}{l}\text { Unilateral nasal congestion usually increases } \\
\text { with inflammation of the nasal mucosa }{ }^{(15)} \text {. }\end{array}$ & Increase of the amplitude of the reciprocal changes ${ }^{(16)}$. \\
\hline Allergy & $\begin{array}{l}\text { Allergen provocation generally increases the } \\
\text { amplitude of the nasal cycle }{ }^{(102)} \text {. }\end{array}$ & $\begin{array}{l}\text { The occurrence and the period of the nasal cycle are not altered }{ }^{(102)} \text {. } \\
\text { Nasal response is still asymmetrical with the congested side before the } \\
\text { challenge responding in most of cases with greater obstruction }{ }^{(104)} \text {. }\end{array}$ \\
\hline Nasal septal deviation & $\begin{array}{l}\text { No differences in terms of occurrence rate and } \\
\text { mean duration of the nasal cycle }{ }^{(108)} \text {. }\end{array}$ & $\begin{array}{l}\text { The amplitude of the changes has been showed to be greater in the } \\
\text { wider side } \mathrm{e}^{(79,107)} \text {. }\end{array}$ \\
\hline OSAS & - & $\begin{array}{l}\text { nCPAP influences the normal physiological nasal cycle during the } \\
\text { awake breathing }{ }^{(114)} \text {. }\end{array}$ \\
\hline
\end{tabular}

strictor system ${ }^{(45,46)}$.

Finally, the oestrogen peak during ovulation is often accompanied by nasal congestion, which alters normal $\mathrm{NC}^{(93)}$, and it is well known that pregnant women often complain of nasal obstruction ${ }^{(94)}$. Although oral contraceptive pills (OCP) have been reported to negatively influence nasal flow ${ }^{(95)}$, modern OCP have no effects on nasal congestion, probably because of the lower oestrogen content ${ }^{(96-98)}$.

\section{Pathologic conditions and NC (Table 2)}

\section{Acute upper respiratory tract infection (URTI)}

An increase in the NC amplitude after the inoculation of nasal drops containing a Coronavirus was reported ${ }^{(99)}$. The amplitude of the spontaneous reciprocal changes in NAR increases during URTI, caused by an increased level of unilateral nasal congestion. The inflammation of the nasal mucosa in fact causes the vasodilatation of the resistance vessels and then an increased filling pressure of the nasal sinusoids, causing congestion only in the nostril with the lowest sympathetic tone ${ }^{(100)}$.

\section{Allergic rhinitis}

Allergic rhinitis strongly influences NC. Huang observed greater amplitudes of nasal patency fluctuation in subjects with a perennial allergic rhinitis when compared to healthy subjects ${ }^{(101)}$. Nasal allergen provocation testing generally increases the amplitude of the NC in allergic rhinitis patients; however, it does not alter the occurrence and the period of the NC, which remains under the control of the central nervous system ${ }^{(102)}$. The maximal NAR increase during the late phase reaction in allergic subjects is up to $300 \%$, whereas the maximal increase in controls due to NC is less than $100 \%^{(103)}$. The obstructive response after acute threshold allergen challenge is typically one-sided. The side with higher NAR before the challenge responds in most of cases with greater obstruction ${ }^{(104,105)}$. When performing nasal challenges, we must remember that NC may confound the test results. NAR changes must be interpreted with caution, and other objective parameters (the nasal secretion amount and the sneezes count) should be used in addition ${ }^{(106)}$.

\section{Nasal septal deviation}

The NC has been found in patients with NSD. When the congestive phase of the NC obstructs the structurally more patent side, bilateral obstruction occurs; conversely, in the decongestive phase, obstruction is relieved as the structurally wider side returns to being more patent ${ }^{(79,107)}$. Sung showed that the amplitude of the minimal cross-sectional area changes was greater in the wider than in the narrower side, but no differences in terms of NC occurrence rate and mean duration were noted, suggesting that the generation of the NC is relatively independent from peripheral anatomic factors ${ }^{(108)}$.

\section{Other pathologies}

Disturbance of the parasympathetic and sympathetic nerves supplying the nasal mucosa has little influence on the NC, which is often preserved ${ }^{(109)}$. Conversely, section of the right cervical sympathetic nerve abolishes the $\mathrm{NC}^{(110,111)}$.

One study evaluated the relation between autism and the NC concluding that patients with autism had no normal NC, as a consequence of an almost continuous left unilateral forced nostril breathing ${ }^{(12)}$. In addition, a NC has been found to have lower frequency in patients with Parkinson's disease suggesting that the mechanism controlled by the sympathetic system can exhibit autonomic dysfunction or hypofunction ${ }^{(113)}$. The NC has also been studied in patients with OSAS: during n-CPAP breathing, both nasal airways experience an elicited geometric pressure that is able to influence the normal physiological NC during awake breathing ${ }^{(114)}$.

\section{NC and surgery}

Every surgical procedure targeting turbinates may cause some effects on the $\mathrm{NC}^{(28,36,115)}$. Submucosal diathermy has been reported to cause a reduction in NC amplitude which may be explained by the cauterization of the venous sinuses in the nasal submucosa ${ }^{(100,116)}$; likewise Tatar reported that submucosal radiofrequency thermal ablation preserves the periodicity of the NC even though it decreases its amplitude ${ }^{(28)}$. Therefore, partial turbinectomy may permanently damage the regulatory 
Table 3. Main methods used for the evaluation of nasal cycle.

\begin{tabular}{|c|c|}
\hline Method & Technique \\
\hline Acoustic rhinometry & $\begin{array}{l}\text { Studies nasal geometry by means of reflected sound and gives information about cross sectional areas and } \\
\text { nasal volumes within a given distance. }\end{array}$ \\
\hline Anterior active rhinomanometry & $\begin{array}{l}\text { Measures the difference in trans-nasal pressure of the airflow through the nasal cavity. The resistance is ob- } \\
\text { tained from these measures by dividing pressure gradient by airflow. In active anterior rhinomanometry the } \\
\text { airflow and pressure gradients are measured through the right and left nostril during a normal respiratory cycle } \\
\text { only one nostril at a time. }\end{array}$ \\
\hline Computational fluid dynamics & $\begin{array}{l}\text { Allows to simulate fluid (either liquid or gas) passing through or around an object with surfaces defined by } \\
\text { boundary conditions. The operator can study all the aspects of the nasal airflow by modifying the thickness of } \\
\text { the inferior and the middle turbinates, as well as that of the nasal septum. In this way it permits the prediction } \\
\text { of fluid movement during different engorgement states of the nasal mucosa in the context of the nasal cycle. }\end{array}$ \\
\hline Long-term rhinoflowmetry & Assesses bilateral nasal flow over a long period of time. Investigates long-term changes of the nasal cycle. \\
\hline Magnetic resonance imaging & $\begin{array}{l}\text { Studies volume changes of the mucosa within the nasal cavity and paranasal sinuses at different times of the } \\
\text { nasal cycle. }\end{array}$ \\
\hline Peak nasal inspiratory flow & Evaluates nasal obstruction by measuring the maximal inspiratory flow through the nose. \\
\hline
\end{tabular}

mechanism for the presence of a turbulent airflow within the $\mathrm{NC}^{(117,118)}$. Conversely, endoscopic sinus surgery has no adverse effects on the NC in terms of pattern of fluctuation, periodicity and amplitude ${ }^{(27)}$.

NC has also been studied in laryngectomized patients and some authors reported that NC disappears after laryngectomy ${ }^{(119,120)}$, while other did not find any difference with the control group $^{(48,49)}$.

\section{NC and drugs}

Nasal decongestants were shown to influence the NC. The administration of nasal topical vasoconstrictor on the congested side is able to cause a prompt cycle reversal ${ }^{(121)}$. While it has been demonstrated that decongestants have little action on the patent side, they cause a significant increase in airflow on the naturally congested side with the least sympathetic nervous activity $^{(122-125)}$. After topical decongestants application, independently from the pattern of NC, the effects last about 5-7 hours in healthy subjects, but only 3.5-6 hours in subjects with nasal pathology, probably due to the increased blood flow observed under inflammatory conditions ${ }^{(126,127)}$. A recent study on intranasal insulin formulation showed no influence on the $\mathrm{NC}^{(128)}$.

\section{Evaluation of the NC (Table 3)}

The evaluation of the NC requires multiple measurements of nasal flow/patency over many hours. Several methods have been used including, among others ${ }^{(4,129-130)}$, rhinomanometry $(\mathrm{RM})^{(6)}$, peak nasal inspiratory flow $(\mathrm{PNIF})^{(30)}, \mathrm{AR}^{(131)}$ and, more recently, $M I^{(2)}$.

Subjective methods are not indicated to evaluate NC as the patients cannot recognize its alterations and about $17 \%$ of patients are unable to recognize the obstructed nasal side ${ }^{(132)}$. However, each of these techniques has its drawbacks in terms of costs, time, reproducibility and patient' compliance. The main methods used for the NC evaluation are summarized in Table3. RM has been standardized as a functional test and extended to describe changes of flows and NAR during the $\mathrm{NC}^{(36,92,118,133,134)}$. $A R$ is a reproducible and non-invasive technique suitable for the objective assessment of the nasal airway, also in neonates ${ }^{(51,131)}$ and in circumstances where airflow through the nose is abolished (i.e. after total laryngectomy) ${ }^{(48,49)}$.

PNIF is a cheap, reproducible and quick method for the objective assessment of nasal airway obstruction, also unilaterally ${ }^{(74,83,135)}$. It has been recently showed that both PNIF and AAR are reliable methods in the evaluation of the NC with a lower variability in PNIF measurements ${ }^{(30)}$. These methods provide only a momentary record of nasal function and do not offer longterm assessment.

Keerl demonstrated the changes of the right and left inferior turbinate volume during a NC by means of a continuous endoscopically filmed-recording, using video sequences of approximately 30 seconds length in defined time intervals ${ }^{(136)}$.

Nasal remission spectroscopy allows single-side continuous monitoring of each side of the nose and has been used in the evaluation of the $\mathrm{NC}^{(137)}$.

Long-term rhinoflowmetry offers the opportunity to assess bilateral nasal flow over a long period of time and is considered a valuable method to investigate long-term changes in the $N C^{(120,138)}$. A new portable device for relatively long-term rhinoflowmetry has also proved to be useful for observing the $N C^{(139)}$. Daily variations in the nasal mucosal volume have also been evaluated by MRI. Although allowing a good evaluation of the nose, MRI is expensive and thus not useful in large scale studies ${ }^{(2)}$. In this regard, computational fluid dynamics (CFD) technology has been applied to quantify nasal physiology and its use is increasing. CT or MRI are necessary in order to capture the individual's nasal anatomy. Three-dimensional digital models of the nasal passages are then created and, through numerical analysis and 
data structures, CFD allows simulation of fluid (either liquid or gas) passing through or around an object with surfaces defined by boundary conditions. The operator can study all the aspects of the nasal airflow by modifying the thickness of the inferior and the middle turbinates, as well as that of the nasal septum. In this way it permits the prediction of fluid movement during different states of nasal mucosal engorgement in the context of the $\mathrm{NC}^{(140-142)}$. Each of these methods evaluates only one aspect of the NC. For this reason their combination may offer a further understanding of nasal physiology. For a proper NC evaluation, it could be suggested to measure unilateral PNIF values every 150 minutes over a total period of 7.5 hours $^{(30)}$. Considering that $\mathrm{NC}$ can be easily influenced by several situations, it must be underlined that its evaluation should not be performed during some conditions, such as allergic rhinitis or URTI.

\section{Conclusions}

When deciding between surgery and medical therapy, the influence of the NC must be considered. Instantaneous measurements of nasal airflows may not reflect how the patient feels over an extended period of time. For this reason, it is crucial to recognize the NC as a normal phenomenon and to differentiate it from the pathologic causes of obstruction.

A critical evaluation of nasal patency must be undertaken by the specialist to provide an accurate picture, obtained through a global nasal evaluation. This will include endoscopy and/or radiology, objective measurements for the evaluation of nasal airflow/patency, including dynamic assessment (eg. with and without decongestant) and a validated disease-specific questionnaire.

\section{Declarations}

Ethics approval and consent to participate: N/A

Consent for publication: the authors give their consent to the publication of the paper

\section{Authorship contribution}

ALP: Pubmed research, writing and discussion. VJL: discussion and supervision. EN: PubMed research. GO: writing, discussion and supervision.

\section{Conflict of interest}

Competing interests: the authors declare no competing interests Funding: nothing to declare

\section{References}

1. Kayser R. Die exact Messung der Luftdurchgangigkeit der Nase. Arch Laryngol Rhinol. 1895; 3:101-103.

2. Kennedy DW, Zinreich SJ, Kumar AJ, Rosenbaum AE, Johns ME. Physiologic mucosal changes within the nose and ethmoid sinus: imaging of the nasal cycle by MRI. Laryngoscope. 1988; 98(9):928-33.

3. Hasegawa M, Kern EB. The human nasa cycle. Mayo Clinic Proc. 1977; 52: 28-34.

4. Heetderks DR. Observations on the reaction of normal nasal mucus membrane. Am J Med Sci. 1927; 174: 23144.

5. Gungor A, Moinuddin R, Nelson RH, Corey JP. Detection of the nasal cycle with acoustic rhinometry: techniques and applications. Otolaryngol Head Neck Surg. 1999;120(2):238-247.

6. Stoksted P. The physiologic cycle of the nose under normal and pathologic conditions. ActaOtolaryngol. 1952;42(1-2):175-9.

7. Gilbert AN, Rosenwasser AM. Biological rhythmicity of nasal airway patency: a re-examination of the 'nasal cycle'. Acta Otolaryngol. 1987;104(1-2):180-6.

8. Wright JW. A consideration of the vascu lar mechanism of the nasal mucous membrane and its relations to certain pathological processes. Am J Med Sci. 1895; 109:516523.

9. Lillie HI. Some practical considerations of the physiology of the upper respiratory tract. J lowa Med Soc. 1923; 13: 403-408.

10. Beickert P. Halbseitenrhythmus der veg etativen Innervation. Arch Ohr-Hals-Heilk.

\section{1; 157: 404-411.}

11. Grevers G. The role of fenestrated vessels for the secretory process in the nasal mucosa: a histological and transmission electron microscopic study in the rabbit. Laryngoscope. 1993; 103: 1255-1258.

12. Cauna N. Blood and nerve supply of the nasal lining. In: Proctor DF, Andersen I, eds. The Nose, Upper Airways Physiology and the Atmospheric Environment. Amsterdam, Elsevier. 1982; pp. 45-69.

13. Ingelstedt S. Humidifying capacity of the nose. Ann OtolRhinolLaryngol. 1970;79(3):475-80.

14. Eccles R. A role for the nasal cycle in respiratory defence. EurRespir J. 1996;9(2):371-6. Review

15. Eccles RB. The nasal cycle in respiratory defence. ActaOtorhinolaryngol Belg. 2000;54(3):281-6.

16. Eccles R, Reilly M, Eccles KS. Changes in the amplitude of the nasal cycle associated with symptoms of acute upper respiratory tract infection. ActaOtolaryngol. 1996;116(1):77-81.

17. White DE, Bartley J, Nates RJ. Model demonstrates functional purpose of the nasal cycle. Biomed Eng Online. 2015;24;14:38

18. Qian W, Djupesland PG, Chatkin.JM, et al. Aspiration flow optimized for nasal nitric oxide measurement. Rhinology. 1999;37:61-65.

19. Werntz DA, Bickford RG, Bloom FE, Shannahoff-Khalsa DS. Alternating cerebral hemispheric activity and the lateralization ofautonomic nervous function. Hum
Neurobiol. 1983; 2: 39-43.

20. Backon J, Matamoros N, Ramirez M, et al. A functional vagotomy induced by unilateral forced right nostril breathing decreases intraocular pressure in open and closed angle glaucoma. Br J Ophthalmol. 1990, 74:607-609.

21. Werntz DA, Bickford RG, Shannahoff-Khalsa DS. Selective hemispheric stimulation by unilateral forced nostril breathing. Hum Neurobiol. 1987; 6: 165-71.

22. Kennedy B, Ziegler MG, Shannahoff-Khalsa D. Alternating lateralization of plasma catecholamines and nasal patency in humans. Life Sci. 1986; 38: 1203-14.

23. Shannahoff-Khalsa D. Lateralized rhythms of the central and autonomic nervous systems. Int J Psychophysiol. 1991;1 1(3):225-51.

24. Kleitman. N. Basic rest-activity cycle-22 years later. Sleep. 1982;5:311-317.

25. AschoffJ, Gerkema M. On the diversity and uniformity of \& radian rhythms. In Ultrudian Rhythms in Physiology and Behavior, Experimental Brain Research, Suppl. 12 Schulz, H. andLavie, P. (Eds.), 1985, SpringerVerlag, Berlin, pp. 321-334.

26. Kern EB. The noncycle nose. Rhinology 1981;19(2):59-74.

27. Anselmo-Lima WT, Lund VJ. The effects of endoscopic sinus surgery on the nasal cycle as assessed by acoustic rhinometry. Am J Rhinol. 2001;15(3):165-8.

28. Tatar A, Altas E. Effects of radiofrequency thermal ablation on the nasal cycle measured using rhinomanometry. Ann OtolRhinolLaryngol. 2014;123(11):771-7. 
29. Williams M, Eccles R. A model for the central control of airflow patterns within the human nasal cycle. J Laryngol Otol. 2016;130(1):82-8.

30. Pendolino AL, Nardello E, Lund VJ, Maculan P, Scarpa B, Martini A, Ottaviano G. Comparison between unilateral PNIF and rhinomanometry in the evaluation ofnasal cycle. Rhinology. 2017 Oct 22. doi: 10.4193/ Rhin 17.168.

31. Eccles R, Lee RL. Nasal vasomotor oscillations in the cat associated with the respiratory rhythm. ActaOtolaryngol. 1981;92(34):357-61.

32. Eccles R. Sympathetic control of nasal erectile tissue. Eur J Respir Dis Suppl. 1983;128 (Pt 1):150-4.

33. Hanif J, Jawad SS, Eccles R. The nasal cycle in health and disease. ClinOtolaryngol. 2000;25:461-7.

34. Dahlström A, Fuxe K. The adrenergic innervation of the nasal mucosa of certain mammals. ActaOtolaryngol (Stockh). 1964; 59: 65-72.

35. Eccles $\mathrm{R}$, Wilson $\mathrm{H}$. The autonomic innervation of the nasal blood vessels of the cat. Physiol (Lond). 1974; 238: 549-60.

36. Stoksted P. Rhinometric measurements for determination of the nasal cycle. ActaOtolaryngol Suppl. 1953;109:159-75.

37. Saroha D, Bottrill I, Saif M, Gardner B. Is the nasal cycle ablated in patients with high spinal cord trauma? ClinOtolaryngol Allied Sci. 2003;28(2):142-5.

38. Stoksted P, Thomsen Ka. Changes in the nasal cycle under stellate ganglion block. Actaotolaryngol Suppl. 1953;109:176-81.

39. Eccles R, Lee RL. The influence of the hypothalamus on the sympathetic innervation of the nasal vasculature of the cat. ActaOtolaryngol (Stockh). 1981;91:127-34.

40. Galioto G, Mevio E, Galioto P, Fornasari G, Cisternino M, Fraietta L. Modifications of the nasal cycle in patients with hypothalamic disorders: Kallmann's syndrome. Ann OtolRhinolLaryngol. 1991;100:559-62.

41. Bremner FD, Nordström JG. A Case of Synchronised Pupillary and Nasal Cycling: Evidence for a Central Autonomic Pendulum? Neuroophthalmology. 2017;41(5):241-246.

42. Marioni G, Ottaviano G, Staffieri A, Zaccaria $M$, et al. Nasal functional modifications after physical exercise: olfactory threshold and peak nasal inspiratory flow. Rhinology. 2010:48(3):277-80.

43. Dallimore NS, Eccles R. Changes in human nasal resistance associated with exercise, hyperventilation and rebreathing ActaOtolaryngol. 1977:84(5-6):416-21.

44. Wolf, S. Reactions in the nasal mucosae; relation of life stress to chronicrhinitis and sinus headache. AMA Arch Otolaryngol. 1954;59(4):461-75.

45. Preece $M$, Eccles $R$. The relationship of skin temperature to the nasal cycle in normal subjects. Rhinology. 1994;32(1):20-4

46. Drettner B. Vascular reactions of the human nasal mucosa on exposure to cold.
ActaOtolaryngol, (Stockh). 1961;Suppl. 166.

47. Mohan SM, Eccles R. Effect of inspiratory and expiratory air flow on congestion and decongestion in the nasal cycle. Indian PhysiolPharmacol. 1989;33(3):191-3.

48. Fisher EW, Liu M, Lung VJ. The nasal cycle after deprivation of airflow: a study of laryngectomy patients using acoustic rhinometry. ActaOtolaryngol. 1994;114:443-6.

49. Fisher EW, Liu M, Lund VJ. Airflow and the nasal cycle: nasal patency fluctuations after laryngectomy. Am J Rhinol 1995;9:175-8.

50. Hildebrandt T, Heppt WJ, Kertzscher U, Goubergrits $L$. The concept of rhinorespiratory homeostasis--a new approach to nasal breathing. Facial Plast Surg. 2013;29(2):8592

51. Baczek M, Hassmann E, Alifier M, IwaszkoKrawczuk W. Acoustic rhinometry assessment of the nasal cycle in neonates. ActaOtolaryngol. 2001;121(2):301-4.

52. Pedersen OF, Berkowitz R, Yamagiwa M, Hilberg O. Nasal cavity dimensions in the newborn measured by acoustic reflections. Laryngoscope. 1994;104(8 Pt 1):1023-8.

53. Drake-Lee AB. Physiology of nose and paranasal sinuses. In Scott-Brown's Otolaryngology, 5th ed. Vol. I. Wright D (Ed.) London: Butterworths, 162-182, 1987.

54. Mayer B, Hoth S, Haels J, Enzmann H. [Regulation of nasal resistance in children] LaryngolRhinolOtol (Stuttg). 1986;65(4):218-

55. Van Cauwenberge PB, Deleye L. Nasa cycle in children. Arch Otolaryngol. 1984;110(2):108-10

56. Fisher EW, Palmer $C R$, and Lund VJ. Monitoring fluctuations in nasal patency in children: Acoustic rhinometry vs. rhinohygrometry. J Laryngol Otol. 1995;109:503508.

57. Gallego AJ, Cavallari FE, Valera FC, Demarco RC, Anselmo-Lima WT. Study of nasal cycles in children by acoustic rhinometry. Am Rhinol. 2006;20(6):560-2.

58. Barontini M, Lazzari JO, Levin G, Armando I, Basso SJ. Age-related changes in sympathetic activity: biochemical measurements and target organ responses. Arch GerontolGeriatr. 1997: 25:175-86.

59. Mirza N, Kroger H, Doty RL. Influence of age on the 'nasal cycle'. Laryngoscope. 1997;107(1):62-6

60. Doty RL, Kamath $\mathrm{V}$. The influences of age on olfaction: a review. Front Psychol. 2014;5:20.

61. Williams MR, Eccles R. The nasal cycle and age. ActaOtolaryngol. 2015;135(8):831-4

62. Kimura A, Chiba S, Capasso R, et al. Phase of nasal cycle during sleep tends to be associated with sleep stage. Laryngoscope. 2013;123:2050-2055

63. Somers VK, Dyken ME, Mark AL, Abboud FM. Sympathetic-nerve activity during sleep in normal subjects. N Engl J Med. 1993;328:303-307.

64. Trinder J, Kleiman J, Carrington M, et al. Autonomic activity during human sleep as a function of time and sleep stage. J Sleep Res. 2001;10: 253-264.
65. Atanasov AT, Dimov PD. Nasal and sleep cycle--possible synchronization during night sleep. Med Hypotheses. 2003:61(2):275-7.

66. Rohrmeier C, Schittek S, Ettl T, Herzog M, Kuehnel TS. The nasal cycle during wakefulness and sleep and its relation to body position. Laryngoscope. 2014;124(6):1492-7.

67. Frye RE, Rosin DF, Morrison AR, LeonSarmiento FE, Doty RL. Modulation of the ultradian human nasal cycle by sleep stage and body position. ArqNeuropsiquiatr. 2017;75(1):9-14.

68. Ozturk D, Araz O, Ucar EY, Akgun M. The effect of unilateral forced nostril breathing on sleep in healthy right-handed men: a preliminary report. Sleep Breath. 2018 Mar 1. doi: 10.1007/s11325-018-1648-0.

69. Miljeteig H, Cole P, Haight JS. Nasal resistance in recumbency and sleep. Rhinology. 1995;33:82-83.

70. Roithmann R, Demeneghi P, Faggiano R, Cury A. Effects of posture change on nasal patency. Braz J Otorhinolaryngol. 2005:71:478-484.

71. Kase Y, Hilberg O, Pedersen OF. Posture and nasal patency: evaluation by acoustic rhiometry. ActaOtolaryngol. 1994;114:70-74.

72. Ottaviano G, Scadding GK, lacono V, Scarpa B, Martini A, Lund VJ. Peak nasal inspiratory flow and peak expiratory flow. Upright and sitting values in an adult population. Rhinology. 2016;54(2):160-3.

73. Jonson B, Rundcrantz H. Posture and pressure within the internal jugular vein. ActaOtolaryngol. 1969;68(3):271-5

74. Ottaviano G, Fokkens WJ. Measurements of nasal airflow and patency: a critical review with emphasis on the use of peak nasal inspiratory flow in daily practice. Allergy. 2016:71(2):162-74

75. Cole P, Haight JS. Posture and the nasal cycle. Ann OtolRhinolLaryngol. 1986 95:233-237.

76. Rao S, Potdar A. Nasal airflow with body in various positions. J Appl Physiol. 1970;28:162-165.

77. Haight JJ, Cole P. Reciprocating nasal airflow resistances. ActaOtolaryngol. 1984;97:9398

78. Haight JS, Cole P. Unilateral nasal resistance and asymmetrical body pressure. J Otolaryngol Suppl. 1986.

79. Cole P, Haight JS. Mechanisms of nasal obstruction in sleep. Laryngoscope. 1984;94:1557-9.

80. Doyle WJ, vanCauwenberge PB. Relationship between nasal patency and clearance. Rhinology. 1987;25(3):167-79.

81. Littlejohn MC, Stiernberg CM, Hokanson JA, Quinn FB Jr, Bailey BJ. The relationship between the nasal cycle and mucociliary clearance. Laryngoscope. 1992;102(2):11720.

82. Ingels KJ, Meeuwsen $\mathrm{F}$, van Strien $\mathrm{HL}$, Graamans K, Huizing EH. Ciliary beat frequency and the nasal cycle. Eur Arch Otorhinolaryngol. 1990;248(2):123-6.

83. Soane RJ, Carney AS, Jones NS, Frier M 
Perkins AC, Davis SS, Illum L. The effect of the nasal cycle on mucociliary clearance. ClinOtolaryngol Allied Sci. 2001;26(1):9-15.

84. Ottaviano G, Staffieri A, Stritoni P, Ermolao A, Coles S, Zaccaria M, Marioni G. Nasa dysfunction induced by chlorinate water in competitive swimmers. Rhinology 2012;50:294-8.

85. Mertz JS, MacCaffrey TV, Kern EB. Role of the nasal airway in regulation of airway resistance during hypercapnia and exercise Otolaryngol Head Neck Surg. 1984;92:302307.

86. Fonseca MT, Voegels RL, Pinto KM Evaluation of nasal volume by acoustic rhinometry before and after physical exercise. Am J Rhinol. 2006;20(3):269-73.

87. Hilberg O, Grymer LF, and Pedersen OF. Spontaneous variations in congestion of the nasal mucosa. Ann Allergy Asthma Immunol. 1995; 74:516-521.

88. Klein R, Pilon D, Prosser S, ShannahoffKhalsa D. Nasal airflow asymmetries and human performance. Biol Psychol. 1986;23(2):127-37.

89. Shannahoff-Khalsa DS, Boyle MR, Buebel ME. The effects of unilateral forced nostril breathing on cognition. Int J Neurosci. 1991;57(3-4):239-49.

90. Sobel N, Khan RM, Saltman A, Sullivan EV, Gabrieli JD. The world smells different to each nostril. Nature. 1999;402(6757):35.

91. Negoias S, Friedrich H, Caversaccio MD, Landis BN. Rapidly fluctuating anosmia: A clinical sign for unilateral smell impairment. Laryngoscope. 2016;126(2):E57-9.

92. Knight LC, Eccles R, Reilly M. Cyclical changes in nasal airway resistance and middle ear pressures. ActaOtolaryngol. 1991;111(4):769-75.

93. Haeggström A, Ostberg B, Stjerna P, Graf $P$, Hallén H. Nasal mucosal swelling and reactivity during a menstrual cycle. ORL J OtorhinolaryngolRelat Spec. 2000;62(1):3942.

94. Ellegård E, Karlsson G. Nasal congestion during pregnancy. ClinOtolaryngol. 1999; 24: 307-311.

95. Bateman ND, Woolford TJ. The rhinologicalside-effects of systemic drugs. ClinOtolaryngol Allied Sci. 2003;28(5):381-5.

96. Wolstenholme CR, Philpott CM, Oloto EJ, Murty GE. Does the use of the combined oral contraceptive pill cause changes in the nasal physiology in young women? Am J Rhinol. 2006; 20: 238-240.

97. Ottaviano G, Scadding GK, Scarpa B, Accordi D, Staffieri A, Lund VJ. Unilateral peak nasal inspiratory flow, normal values in adult population. Rhinology. 2012; 50:386-392

98. Ottaviano G, Cosmi E, lacono V, Scarpa B, Staffieri A, Scadding GK. Does the contraceptive pill influence peak nasal inspiratory flow values? Rhinology. 2014;52(4):355-9.

99. Bende M, Barrow I, Heptonstall J, Higgins PG, Al-Nakib W, Tyrrell DA, Akerlund A. Changes in human nasal mucosa during experimental coronavirus common colds. ActaOtolaryngol. 1989;107(3-4):262-9.
100. Eccles R. Nasal airflow in health and disease. ActaOtolaryngol. 2000;120(5):580-95. Review.

101. Huang ZL, Ong KL, Goh SY, Liew HL, Yeoh $\mathrm{KH}$, Wang DY. Assessment of nasal cycle by acoustic rhinometry and rhinomanometry. Otolaryngol Head Neck Surg. 2003;128(4):510-6

102. Kim JK, Cho JH, Jang HJ, Shim DB, Shin HA The effect of allergen provocation on the nasal cycle estimated by acoustic rhinometry. ActaOtolaryngol. 2006;126(4):390-5.

103.Wang D, Clement P. Assessment of early and late phase nasal obstruction in atopic patients after nasal allergen challenge. ClinOtolaryngol. 1995;20:368-73.

104. Brooks C, Karl K, Francom S. Unilaterality of obstruction after acute nasal allergen provocation. Relation of allergen dose, nasal reactivity and the nasal cycle. ClinExp Allergy. 1991; 21(5): 583-587.

105. Gotlib T, Samoliński B, Grzanka A. Effect of the nasal cycle on congestive response during bilateral nasal allergen provocation. Ann Agric Environ Med. 2014;21(2):290-3.

106.Pirilä T, Talvisara A, Alho OP, Oja H. Physiological fluctuations in nasal resistance may interfere with nasal monitoring in the nasal provocation test. ActaOtolaryngol. 1997;117(4):596-600.

107. Arbour P, Kern EB. Paradoxical nasal obstruction. Can J Otolaryngol. 1975;4(2):333-8.

108. Sung YW, Lee MH, Kim IJ, Lim DW, Rha KS, Park Cl. Nasal cycle in patients with septal deviation: evaluation by acoustic rhinometry. Am J Rhinol. 2000; 14(3):171-4.

109.Ishii J, Ishii T, Ito M. The nasal cycle in patients with autonomic nervous disturbance. ActaOtolaryngol Suppl. 1993;506:516.

110.Eccles R. The domestic pig as an experimental animal for studies on the nasal cycle. ActaOtolaryngol. 1978;85(5-6):431-6.

111. Eccles R. A method for studying the cyclic changes in nasal resistance in the anaesthetized pig [proceedings]. J Physiol. 1978;282:1P-2P.

112. Dane S, Balci N. Handedness, eyedness and nasal cycle in children with autism. Int J DevNeurosci. 2007;25(4):223-6.

113. Kotan D, Tatar A, Aygul R, Ulvi H. Assessment of nasal parameters in determination of olfactory dysfunction in Parkinson's disease. J Int Med Res. 2013:41(2):334-9.

114. White DE, Bartley J, Shakeel M, Nates RJ, Hankin RK. Nasal airway responses to nasal continuous positive airway pressure breathing: An in-vivo pilot study. J Biomech. 2016 14:49(9):1887-90.

115. Kuening J. On the nasal cycle. IntRhinol. 1968; 6: 99-136.

116. Quine, S.M., Aitken, P.M., Eccles, R. Effect of submucosal diathermy to the inferior turbinates on unilateral and total nasal airflow in patients with rhinitis. ActaOtolaryngol. 1999:119, 911-915.

117. Mlynski G, Beule A. Diagnostic methods of nasal respiratory function. HNO. 2008;56(1):81-99.
118.Lang C, Grützenmacher S, Mlynski B, Plontke S, Mlynski G. Investigating the nasal cycle using endoscopy, rhinoresistometry, and acoustic rhinometry. Laryngoscope. 2003;113(2):284-9.

119. Havas TE, Cole P, Gullane PJ, Kassel R, Kamino D. The nasal cycle after laryngectomy. ActaOtolaryngol. 1987;103(1-2):111-6.

120. Ogura Jh, Stokstead P. Rhinomanometry in some rhinologic diseases. Laryngoscope. 1958;68(12):2001-14

121. Jawad SS, Eccles R. Effect of pseudoephedrine on nasal airflow in patients with nasal congestion associated with common cold. Rhinology. 1998;36(2):73-6.

122. Flanagan P, Eccles R. Physiological versus pharmacological decongestion of the nose in healthy human subjects. ActaOtolaryngol. 1998;118(1):110-3.

123. Williams RG, Eccles R. Nasal airflow asymmetry and the effects of a topical nasal decongestant. Rhinology. 1992;30(4):27782.

124.Principato JJ, Ozenberger JM. Cyclical changes in nasal resistance. ArchOtolaryngol. 1970;91(1):71-7.

125. Soubeyrand L. Action des médicamentsvaso-moteurssur le cycle nasal et la fonctionciliaire. Rev LaryngolOtolRhinol (Bord).1964; 85: 49-113.

126. Braun T, Rich M, Berghaus A, Kramer MF. Effects of oxymetazoline nasal spray on the nasal cycle assessed by long-term rhinoflowmetry. Rhinology. 2012;50(4):370-5.

127. Leary AC, Dowling M, Cussen K, O'Brien J, Stote RM. Pharmacokinetics and pharmacodynamics of intranasal insulin spray (Nasulin) administered to healthy male volunteers: infuence of the nasal cycle. J Diabetes Sci Technol. 2008;2(6):1054-60.

128. Fullton JM, Drake AF, Fischer ND, Bromberg PA. Frequency dependence of effective nasal resistance. Ann OtolRhinolLaryngol. 1984:93(2 Pt1):140-5.

129. Canter RJ. A non-invasive method of demonstrating the nasal cycle using flexible liquid crystal thermography. ClinOtolaryngol Allied Sci. 1986;1 1(5):329-36.

130.Juto JE, Lundberg C. Variation in nasal mucosa congestion during rest. ActaOtolaryngol (Stockh) 1984; 98: 136-9.

131. Fisher EW, Scadding GK, and Lund VJ. The role of acoustic rhinometry in studying the nasal cycle. Rhinology. 1993:31:57-61.

132. Thulesius HL, Cervin A, Jessen M. The importance of side difference in nasal obstruction and rhinomanometry: a retrospective correlation of symptoms and rhinomanometry in 1000 patients. ClinOtolaryngol. 2012 Feb;37(1):17-22.

133. Lenz H, Theelen W, Eichler J. [Nasal cycle using rhinomanometric measurements]. HNO. 1985; 33(2):58-61. German.

134. Eccles R. Rhinomanometry and nasal challenge. In Scott Brown's Otolaryngology, Mackay I.S. \& Bull T.R. (eds). 1987; pp. 40-53. Butterworths, London, UK.

135. Holmström M, Scadding GK, Lund VJ, Darby YC. Assessment of nasal obstruction. 
A comparison between rhinomanometry and nasal inspiratory peak flow. Rhinology. 1990;28:191-196.

136. Keerl R, Weber R, Huppmann A, Draf W. [Imaging time-dependent changes in the nasal mucosa using the most modern morphing software]. Laryngorhinootologie. 1995;74(7):413-8.

137.Wüstenberg EG, Hampel U, Schleicher E, Hüttenbrink KB, Zahnert T. [Bilateral nasal remission spectroscopy allows the side separated continuous measurement of changes in swelling of the nasal mucosa]. HNO. 2007:55(4):254-7. German.

138. Grützenmacher S, Lang C, Mlynski R, Mlynski B, Mlynski G. Long-term rhinoflowmetry: a new method for functional rhinologic diagnostics. Am J Rhinol.
2005;19(1):53-7

139. Ohki M, Ogoshi T, Yuasa T, Kawano K Kawano M. Extended observation of the nasal cycle using a portable rhinoflowmeter. J Otolaryngol. 2005;34(5):346-9.

140. Gaberino C, Rhee JS, Garcia GJ. Estimates of nasal airflow at the nasal cycle mid-point improve the correlation between objective and subjective measures of nasal patency. RespirPhysiolNeurobiol. 2017;238:23-32.

141. Jo G, Chung SK, Na Y. Numerical study of the effect of the nasal cycle on unilateral nasal resistance. RespirPhysiolNeurobiol. 2015:219:58-68

142. Patel RG, Garcia GJ, Frank-Ito DO, Kimbell JS, Rhee JS. Simulating the nasal cycle with computational fluid dynamics. Otolaryngol Head Neck Surg. 2015;152(2):353-60.
Giancarlo Ottaviano, MD, PhD

Department of Neurosciences

Otolaryngology Section

University of Padova

Via Giustiniani 2

35128 Padova

Italy

Tel. +39 (0)498214470

Fax: +39 (0)498213113

E-mail: giancarlo.ottaviano@unipd.it 